\title{
EFFECT OF TOPICAL HUMIC ACID ON EXCISIONAL PALATAL WOUND HEALING: A HISTOPATHOLOGICAL AND HISTOMORPHOMETRIC STUDY IN RATS
}

\begin{abstract}
Objective: The purpose of the present study was to examine the effects of topical humic acid application on healing in oral mucosa wound in rats.

Material and Methods: A total of 12-week-old 72 Wistar male rats weighing 280-300 gr were used in the study. The rats were randomly grouped in 4 groups as the Control Group (K) to which no applications were made, Chlorhexidine (0.12\%) Group (CHX), $80 \mathrm{mg} / \mathrm{kg}$ Humic Acid Group (HA80), and $150 \mathrm{mg} / \mathrm{kg}$ Humic Acid Group (HA150). Mucosal defects of 5-mmdiameter were induced with punch in the palatal areas of the rats. These groups were further divided into 3 sub-groups to be sacrificed on days 7, 14 and 21. Epithelization, ulceration, polymorphic nuclear leukocytes (PNL), mononuclear cells (MNL), fibroblast and vascularization were examined in histopathologic evaluations. In addition, photos of the tissue samples were taken and transferred to the computer medium for histo-morphometric examinations.
\end{abstract}

Results: As a result of the statistical analyses, no significant differences were detected among the groups in terms of epithelization degree, PNL and MNL cell infiltration on days 7, 14 and 21. The ulcerated areas were low in HA150 Group compared to the other groups, and there was a significant difference in this respect $(\mathrm{p}<0.05)$. Vascularization degrees were evaluated, the K Group and HA150 Group showed better results on day 7 ( $\mathrm{p}<0.05)$. On days 14 and 21 , no significant differences were detected among the groups $(\mathrm{p}>0.05)$. Wound area measurement scores were lower in HA150 Group compared to the other groups, and this result showed that the healing in HA150 Group was better $(\mathrm{p}<0.05)$.

Conclusions: As a result of the present study, it was found that humic acid increased wound healing in oral cavity.

Keywords: Wound, palatal mucosa, chlorhexidine, humic acid.
Yusuf Ziya Dönmez ${ }^{1}$

*Aysun Akpınar ${ }^{2}$

Ömer Fahrettin Göze ${ }^{3}$

ORCID IDs of the authors:

Y.Z.D. $\quad 0000-0002-1021-5756$

A.A. $\quad 0000-0002-6740-3598$

Ö.F.G. $\quad 0000-0002-6451-2967$

\footnotetext{
${ }^{1}$ Periodontal Specalist; Private Dentalpark Oral and Dental Health Center, Kayseri, Turkey.

${ }^{2}$ Department of Periodontology, Faculty of Dentistry, Bursa Uludağ University, Bursa, Turkey.

3 Department of Pathology, Faculty of Medicine, Sivas Cumhuriyet University, Sivas, Turkey.
}

Received : 27.01 .2021

Accepted : 08.12 .2021

How to Cite Dönmez YZ, Akpınar A, Göze ÖF. Effect of Topical Humic Acid on Excisional Palatal Wound Healing: A Histopathological and Histomorphometric Study in Rats. Cumhuriyet Dent J 2021;24:4:326-336.

*Corresponding Author:

Department of Periodontology, Faculty of Dentistry, Bursa Uludağ University, Bursa, Turkey.

E-mail: aysunakpinar73@hotmail.com 


\section{INTRODUCTION}

Wound healing is characterized by coming together of epithelial, endothelial, inflammatory cells, platelets and fibroblasts, and performing their normal functions in a certain order. Wounds in the mouth that occur due to physical, chemical, surgical or microscopic reasons can negatively affect the vital functions, work and social life, nutrition, and breathing of people. For this reason, it is desired that such wounds heal as soon as possible. ${ }^{1}$ Previous researchers have worked on materials and techniques that would accelerate the healing process for many years, and examined the effects of different wound healing agents on different types of wounds. ${ }^{2-4}$ In addition, many agents have been used to decrease post-operative complications and to accelerate oral wound healing. Topical antimicrobials are recommended because of these effects. ${ }^{5-8}$

Humic substances, which constitute one of the largest carbon reserves in the nature, consist of many different sources like lignite, peat, live plants, algae, etc. In medicine, humic substances were used for different purposes against different diseases 3.000 years ago. ${ }^{9}$ The idea of using humic substances in pharmaceutical industry emerged because of their antiviral activities, and anti-inflammatory and proinflammatory characteristics, effects on blood coagulation and fibrinolysis, estrogenic activity, antibacterial, antiallergic, and antiulcerogenic properties. ${ }^{9}$ İn the structure of humic acids; there are molecules of various components such as amino acids, lignins, pectins or carbohydrates. ${ }^{10,11}$ The main elements that make up the structure of humic acid are carbon, hydrogen, oxygen, nitrogen and sulfur (C, H, O, N and S). ${ }^{12}$

Previous studies showed that humic acid does not have any toxicity. ${ }^{13-18}$ In an experimental bone fracture study, it was determined that osteoid formation and mineralization were accelerated with humic acid application during the first week after fracture, while osteoid formation and mineralization were significantly reduced when humic acid treatment was delayed to the second week. ${ }^{19}$ Another study on bone fractures in children found that humic acid has a positive effect on bone regeneration. ${ }^{20}$ In a study by Derre et $a .^{21}$, experimentally induced herpes infection in the mouse ear was treated by applying a topical humic acid-derived substance, and it was concluded that the humic acid-derived agent significantly reduced or completely suppressed the infection. Vucskits et al. $^{22}$ In their study in rats, they stated that the humic acid diet both increases the immune response and prolongs the immune response time. Ji et $a l^{23}$ conducted a study on rats, and showed that humic acid accelerates the healing of wounds on the surface of the skin. Calisir et al. ${ }^{24}$ reported that humic acid was effective in closing wounds on the palatal mucosa in rats. Although these results suggest that humic acids may be useful in wound healing in palatal mucosa, there is currently not enough evidence showing the effects of humic acid on wound healing in oral cavity. The purpose of this study was to evaluate the effects of humic acid on the healing of excisional wounds in the palatal mucosa of rats.

\section{MATERIALS AND METHODS}

Approval was obtained from Sivas Cumhuriyet University, Animal Experiments Ethics Board on 01.02.2018 and with number 136 for the present study. As subjects, 12-week-old 72 Wistar male rats with an average weight of 280-300 g were used. The rats in each group were fed in separate cages under the same conditions. All rats were fed with standard feed and water, observing 12-hournight/day cycle at $21 \pm 1^{\circ} \mathrm{C}$ temperature and 40 $60 \%$ humidity. The rats were kept in metal cages for 10 days to adjust to new living conditions before the study commenced. The experimental stages of the present study were conducted at Sivas Cumhuriyet University, Medical Faculty Animal Laboratory.

\section{Surgical Method}

The rats were anesthetized by injecting $30 \mathrm{mg} / \mathrm{kg}$ Ketamine-HCL (Ketalar, Eczacibasi, Turkey) and 5 $\mathrm{mg} / \mathrm{kg}$ Xylazine HCL (Rompun, Bayer, Germany) before creating the wounds in veterinary control. Five-mm-diameter mucosal defects were created in the rats in the palatal area. A round and stainless steel punch was used in this process. After hemorrhage control, the wounds were left to 
secondary recovery. The first day when the wounds were created was recorded as day 0 .

\section{Preparation and Application of Humic Acid}

Considering the weight of the rats, appropriate concentrations of humic acid was prepared for the rats in each group. The amount of humic acid (0.5 cc) was applied topically with a blunt-tip injector.

\section{Creation of Groups}

The rats were randomly selected and divided into 4 main groups as the Control Group (K) $(n=18)$, Chlorhexidine Gluconate Group $(0.12 \%)$ (CHX) $(\mathrm{n}=18), 80 \mathrm{mg} / \mathrm{kg}$ Humic Acid Group (HA80) $(\mathrm{n}=18)$, and $150 \mathrm{mg} / \mathrm{kg}$ Humic Acid Group (HA150) (n=18). After creating wounds in the palatal areas of the rats, the rats were divided further into 3 sub-groups to be sacrificed on days 7, 14 and 21.

\section{Histological evaluation}

Full-layer samples were taken from the wounds created in the palatal areas in all groups on days 7 , 14 and 21 including $1 \times 1 \mathrm{~cm}$ of intact tissue. These tissue samples underwent routine tissue follow-up procedures in the Department of Pathology of Sivas Cumhuriyet University, Faculty of Medicine. The samples taken from the rats with biopsies were fixed for 48 hours in 10\% formalin solution for light microscope examination, and were blocked by using routine paraffin blocking method. The slides were prepared by taking three 3-4- $\mu \mathrm{m}$ sections from the blocks with microtome (Leica D80 LX, Germany). The slides were then evaluated in the light microscope with Hematoxylin Eosin Staining to observe inflammatory changes and to show morphology in healed wounds.

Histopathological examination was performed by the same pathologist who was blinded about the groups. In histopathological evaluation, Epithelization and Ulceration were evaluated as Yes (1) and No (0), and Polymorphic Nuclear Leukocytes (PNL), Mononuclear Cells (MNL), Fibroblast and Vascularization degrees were rated as No (0), Low (1), Moderate (2), or Severe (3).

\section{Photographical evaluation}

The course of healing in all the defects on days 7 ,
14 and 21 was photographed (Canon EOS 1000D, Tokyo/Japan) after the tissues taken from the palatal areas of the rats were fixed under $\mathrm{x} 8$ magnification on stereomicroscope (Carl Zeiss Stemi DV4, Germany). After the photographs were taken, the images were transferred to the computer medium. The measurements of the wound surface areas were performed by using the ImageJ and NIH Image Software, National Institutes of Health, Bethesda, Md. program.

\section{Statistical Method}

The data of the study were uploaded to the SPSS (Ver 22.0) program; and since the parametric test assumptions were met in the evaluation of the data, the Kolmogorov - Simirnov Test was used. Then, variance analysis was made. When measurements obtained from more than two independent groups were compared, and when the difference between the groups was found to be significant as a result of the analyses, the Tukey Test was used to find the group(s) that differed. When the scores at different times were compared, the Kruskall-Wallis test was used. The Man-Whitney U test was employed when the difference was found to be significant as a result of the analyses to find the group that differed. The Chi-Square test was used in the evaluation of the qualitative data obtained with numbers, and the error level was taken as 0.05 .

\section{RESULTS}

No significant differences were found in terms of epithelization level, PNL and MNL cell infiltration and fibroblast values among the groups on days 7, 14 and 21. In terms of ulcerated areas, the difference between HA150 Group and other groups on days 7 and 14 was statistically significant $(\mathrm{p}<0.05)$. Ulceration was lower in HA150 Group than in any other group. On day 21, the difference was statistically significant between HA150 Group and $\mathrm{K}$ and CHX Group, and between HA80 Group and K and CHX Group $(\mathrm{p}<0.05)$; however, there was no statistically significant difference between HA80 Group and HA150 Group. When vascularization values were evaluated, it was found that the vascularization values were higher at statistically significant level on day 7 in Group K and HA15 Group, compared 
to the CHX and HA80 Group ( $\mathrm{p}<0.05)$. On days

similar level in all groups (Table 1).

14 and 21 , the degree of vascularization was at a

Table 1: Statistical analysis results of histopathologic variables

\begin{tabular}{|c|c|c|c|c|c|c|}
\hline & & $\begin{array}{c}\text { K Group } \\
(n=6)\end{array}$ & $\begin{array}{c}\text { CHX Group } \\
(n=6)\end{array}$ & $\begin{array}{l}\text { HA80 Group } \\
\qquad(n=6)\end{array}$ & $\begin{array}{l}\text { HA150 Group } \\
\qquad(\mathrm{n}=6)\end{array}$ & $\mathrm{p}$ \\
\hline \multirow{6}{*}{ ڤે } & Epithelization & $0.66 \pm .51$ & $1.00 \pm .00$ & $1.00 \pm .00$ & $1.00 \pm .00$ & 0.223 \\
\hline & Ulceration & $1.00 \pm .00$ & $0.50 \pm .54^{\mathrm{a}}$ & $0.83 \pm .40$ & $0.16 \pm .40^{\mathrm{b}}$ & $0.016^{*}$ \\
\hline & MNL & $1.50 \pm .54$ & $2.00 \pm .89$ & $2,66 \pm .81$ & $2.33 \pm .88$ & 0.088 \\
\hline & PNL & $1.50 \pm .54$ & $1.33 \pm 1.03$ & $2.66 \pm .81$ & $2.16 \pm .98$ & 0.066 \\
\hline & Fibroblast & $3.00 \pm .00$ & $2.00 \pm .89$ & $2.00 \pm .75$ & $2.16 \pm .98$ & 0.537 \\
\hline & Vascularization & $2.00 \pm .00$ & 1.33 .75 & $1.33 \pm .75$ & $2.00 \pm .00$ & 0.227 \\
\hline \multirow{6}{*}{ 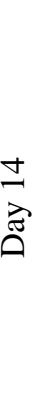 } & Epithelization & $0.66 \pm .51$ & $1.00 \pm .00$ & $1.00 \pm .00$ & $1.00 \pm .00$ & 0.223 \\
\hline & Ulceration & $0.83 \pm .40$ & $0.83 \pm 0.40$ & $0.66 \pm .57$ & $0.00 \pm .00^{c}$ & $0.014 *$ \\
\hline & MNL & $1.50 \pm .54$ & $1.66 \pm .81$ & $1.50 \pm .54$ & $2.33 \pm .81$ & 0.211 \\
\hline & PNL & $2.00 \pm .63$ & $1.33 \pm .51$ & $1.50 \pm .54$ & $2.33 \pm .81$ & 0.121 \\
\hline & Fibroblast & $1.54 \pm .54$ & $2.00 \pm .63$ & $2.00 \pm .63$ & $2.16 \pm .75$ & 0.321 \\
\hline & Vascularization & $1.83 \pm .40$ & $1.50 \pm .54$ & $1.66 \pm .51$ & $1.83 \pm .75$ & 0,695 \\
\hline \multirow{6}{*}{$\begin{array}{l}\vec{N} \\
\overrightarrow{\tilde{D}} \\
\text { Dे }\end{array}$} & Epithelization & $0.83 \pm .40$ & $1.00 \pm .00$ & $1.00 \pm .00$ & $1.00 \pm .00$ & 0.406 \\
\hline & Ulceration & $0.67 \pm .57$ & $0.50 \pm .54$ & $0.16 \pm .40^{\mathrm{d}}$ & $0.00 \pm .00^{\mathrm{e}}$ & $0.002 *$ \\
\hline & MNL & $1.50 \pm .54$ & $1.00 \pm .00$ & $1.00 \pm .00$ & $1.16 \pm .40$ & 0.075 \\
\hline & PNL & $1.16 \pm .51$ & $1.00 \pm .00$ & $1.00 \pm .00$ & $1.00 \pm .63$ & 0.052 \\
\hline & Fibroblast & $2.00 \pm .89$ & $1.66 \pm .51$ & $2.00 \pm .00$ & $2.00 \pm .89$ & 0.771 \\
\hline & Vascularization & $1.16 \pm .40$ & $1.33 \pm .75$ & $1.66 \pm .51$ & $1.66 \pm 51$ & 0.227 \\
\hline
\end{tabular}

*p<0.05; C: Control; CHX: Chlorhexidine; HA80: Humic Acid 80 mg/kg; HA150: Humic Acid 150 mg/kg; MNL: Mononuclear cell; PNL:

Polymorph nuclear leukocyte

$a=$ The difference between $C H X, K$ and HA80 was statistically significant

$b=$ The difference between HA150 and other groups was statistically significant

$c=$ The difference between HA150 and other groups was statistically significant

$d=$ The difference between HA80 Group, CHX and K Group was statistically significant

$e=$ The difference between HA150 Group, CHX and K Group was statistically significant

When the wound surface area measurements between the groups on days 7 and 14 were evaluated, it was determined that none of the groups was superior in terms of healing. However, on day 21 , HA150 Group was found to be more effective in decreasing the wound surface area than other groups (Table 2). 
Table 2: Statistical analysis results of the intergroup wound area surface measurements

\begin{tabular}{|c|c|c|c|c|}
\hline & Groups & $\mathbf{n}$ & Average Area & p \\
\hline \multirow{4}{*}{ Day 7} & $\mathrm{~K}$ & 6 & $13.14 \pm 2.64$ & \multirow{4}{*}{0.432} \\
\hline & CHX & 6 & $15.00 \pm 6.13$ & \\
\hline & HA80 & 6 & $17.13 \pm 3.16$ & \\
\hline & HA150 & 6 & $14.56 \pm 7.21$ & \\
\hline \multirow{4}{*}{ Day 14} & $\mathrm{~K}$ & 6 & $12.10 \pm 5.10$ & \multirow{4}{*}{0.358} \\
\hline & CHX & 6 & $10.80 \pm 4.93$ & \\
\hline & HA80 & 6 & $8.53 \pm 3.55$ & \\
\hline & HA150 & 6 & $8.88 \pm 5.62$ & \\
\hline \multirow{4}{*}{ Day 21} & $\mathrm{~K}$ & 6 & $7.33 \pm 3.05$ & \multirow{4}{*}{$0.035^{*}$} \\
\hline & $\mathrm{CHX}$ & 6 & $5.88 \pm 1.96$ & \\
\hline & HA80 & 6 & $6.86 \pm 3.03$ & \\
\hline & HA150 & 6 & $2.70^{\mathrm{a}} \pm 2.72$ & \\
\hline
\end{tabular}

*p<0.05; C: Control; CHX: Chlorhexidine ; HA80: Humic Acid 80 mg/kg; HA150: Humic Acid 150 mg/kg

$\mathrm{a}=$ The difference between HA150 Group and K, CHX and HA80 Group was statistically significant

When the wound surface area measurements within the groups were compared, it was days 7 , 14 and 21 in the $\mathrm{K}$ group. In the CHX group, the healing on day 21 was better than the healing on day 7 , and this difference was statistically significant $(\mathrm{p}<0.05)$. According to the area measurement results in the HA80 group, the healing on day 14 was better than the healing on day 7 and the healing on day 21 was better than the healing on day 7 . In the HA150 group, the healing on the 21 st day was higher to the healing on the 7th day, while the difference between the healing on the 7th day and the 14th day and the healing in the 14th and 21 st day were not statistically significant (Table 3).

Table 3: Statistical analysis results of the intragroup wound area surface measurements

\begin{tabular}{|c|c|c|c|}
\hline \multicolumn{2}{|l|}{ Groups } & \multirow{2}{*}{$\begin{array}{l}\text { Average area } \\
13.14 \pm 2.64\end{array}$} & \multirow[t]{2}{*}{ p } \\
\hline & 7. Day & & \\
\hline N & 14. Day & $12.10 \pm 5.10$ & 0.058 \\
\hline & 21. Day & $7.33 \pm 3.05$ & \\
\hline & 7. Day & $15.00^{\mathrm{a}} \pm 6.13$ & \\
\hline $\mathrm{CHX}$ & 14. Day & $10.80 \pm 4.93$ & $0.046^{*}$ \\
\hline$(n=6)$ & 21. Day & $5.88^{\mathrm{a}} \pm 1.96$ & \\
\hline & 7. Day & $17.13^{b c} \pm 3.16$ & \\
\hline & 14. Day & $8.53^{\mathrm{b}} \pm 3.55$ & $0.001 *$ \\
\hline$(n=6)$ & 21. Day & $6.86^{\mathrm{c}} \pm 3.03$ & \\
\hline & 7. Day & $14.56^{\mathrm{d}} \pm 7.21$ & \\
\hline $\begin{array}{l}\text { НАISU } \\
(n=6)\end{array}$ & 14. Day & $8.88 \pm 5.62$ & $0.005^{*}$ \\
\hline & 21. Day & $2.70^{\mathrm{d}} \pm 2.72$ & \\
\hline
\end{tabular}

*p<0.05; C: Control; CHX: Chlorhexidine ; HA80: Humic Acid 80 mg/kg; HA150: Humic Acid 150 mg/kg

$\mathrm{a}=$ The difference between days 7 and 21 in area measurements in CHX Group was statistically significant

$\mathrm{b}=$ The difference between days 7 and 14 in area measurements in HA80 Group was statistically significant

$\mathrm{c}=$ The difference between days 7 and 21 in area measurements in HA80 Group was statistically significant

$\mathrm{d}=$ The difference between days 7 and 21 in area measurements in HA150 Group was statistically

significant

\section{DISCUSSION}

The present study is the first study in which the effects of two different humic acid concentrations was evaluated on wound healing. In the present study, the groups to which $80 \mathrm{mg} / \mathrm{kg}$ humic acid,
$150 \mathrm{mg} / \mathrm{kg}$ humic acid, chlorhexidine gluconate, and no agent application were compared in the defects created on palatal mucosa of rats. Humic substances, which are mostly found in lignite, peat, soil and water, have antiviral, antibacterial, 
antitoxic, antiulcerogenic, antiarthritic, antiallergic, immunomodulator, and antiinflammatory characteristics. ${ }^{25}$ Humic acids are the most commonly found forms of organic carbon in the nature, and have strong antiinflammatory effects, which they show by inhibiting the release of IL- $1 \beta$ and TNF- $\alpha$ activated by leukocytes. ${ }^{13,26}$ It was shown that humic acid decreases lipopolysaccharidemediated adhesion molecules cultured from human umbilical vein endothelial cells (ICAM-1, VCAM -1 and E-selectin) at significant levels. ${ }^{27}$ This may be one of the ways in which the possible effects of humic acid in the inflammatory process is explained.

When intragroup wound surface area scores were compared, it was determined that the healing on days 7, 14 and 21 was similar in Group K. The healing on day 21 was better compared to the healing on day 7 in CHX Group, and the difference was statistically significant $(\mathrm{p}<0.05)$. According to the field measurement results in HA80 Group, the healing on day 14 was better than that on day 7, and the healing on day 21 was better than that on day 7. In HA150 Group, the healing on day 21 was better than that on day 7; however, the differences between healing scores on day 7 and 14, and the differences between the healing scores on day 14 and 21 were not found to be statistically significant.

The still epithelial cells become cells that migrate to the wound area with the effect of growth factors secreted from platelets and macrophages. The formation of epithelium begins with the migration of epidermal cells in the wound edge and skin supplements. ${ }^{26}$ Mariano et al. $^{28}$ reported that the application of $0.2 \%$ chlorhexidine on the palatal mucosa defects induced in rats shortened healing time and facilitated wound epithelization. Teixeira et al. $^{29}$ created wounds on rats' tongues, and showed that the application of $0.12 \%$ chlorhexidine was highly effective on ulcerations as of the first day. Abshenas et al. ${ }^{30}$ and Brzozowski et al. ${ }^{31}$ reported that the application of humic acid accelerated wound healing at significant levels in rats in which they created gastric ulcers.
The regeneration and repair of the epithelium is an important part in wound healing. The major function of epithelium is to create a barrier between the body surface and the environment. After an injury, the connection to the adjacent cells on the edge of the wound is disrupted.

In the present study, when epithelization values on days 7, 14 and 21 were evaluated, there was no statistically significant difference between the groups. However, in the HA150 Group, epithelization was found to be better than in the other groups. The lowest level was in Group $\mathrm{K}$ (Figure 1,2 and 3).

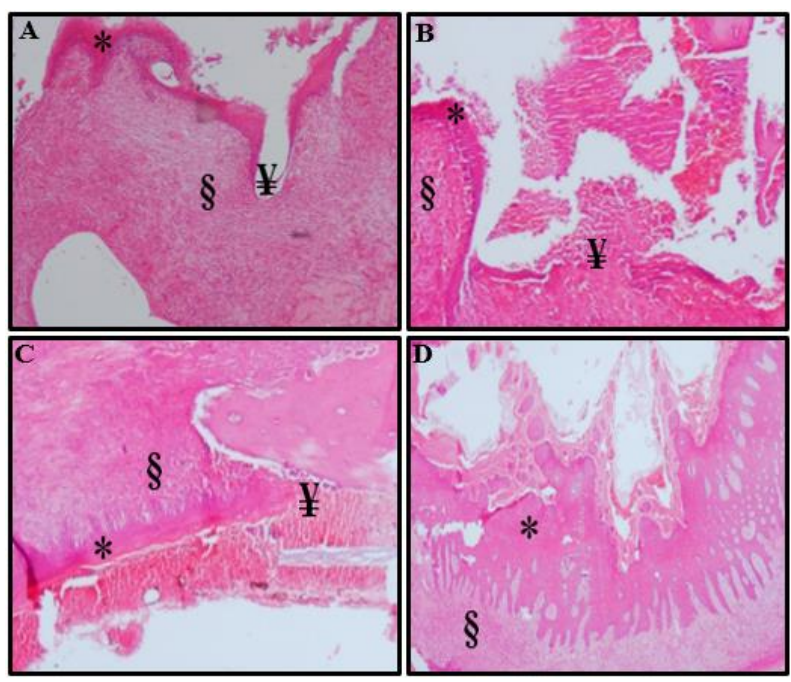

Figure 1: Day 7, the surface epithelium $(*)$, ulceration $(¥)$ and inflammatory granulation tissue $(\S)$ of $\mathrm{K}(\mathrm{A}), \mathrm{CHX}(\mathrm{B}), \mathrm{HA} 80$ (C) and HA150 (D) Groups (Hematoxylin-Eosin X40)

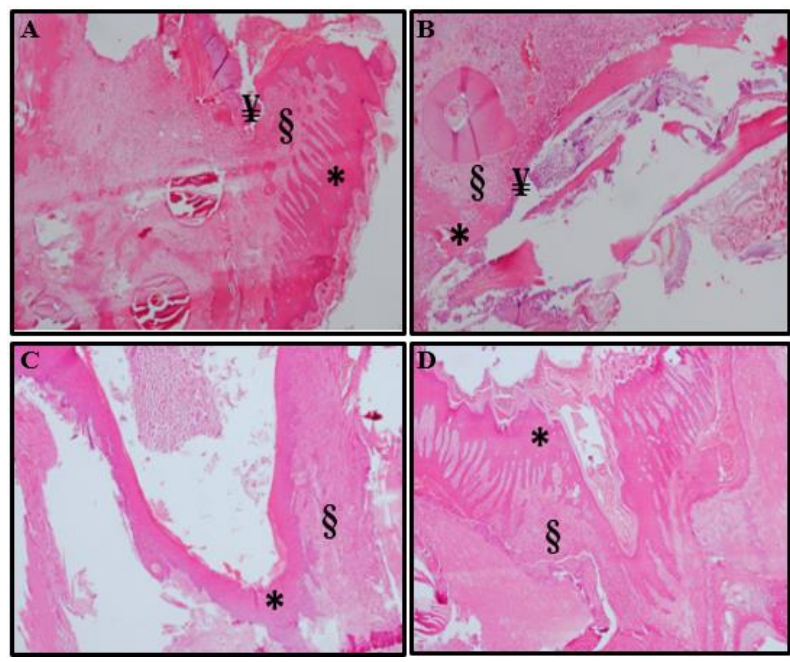

Figure 2: Day 14, the surface epithelium (*), ulceration (¥) and inflammatory granulation tissue (§) of K (A), CHX (B), HA80 (C) and HA150 (D) Groups (Hematoxylin-Eosin X40). 


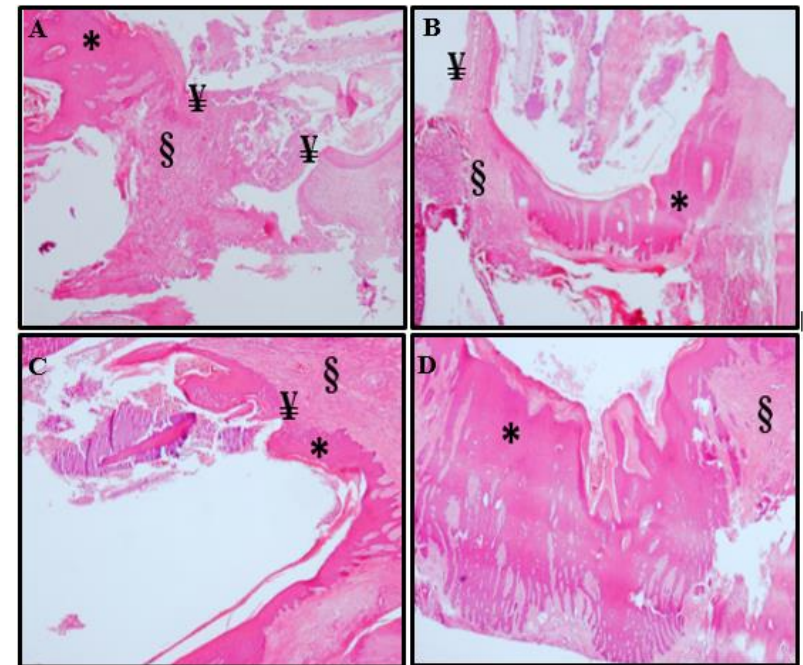

Figure 3: Day 21, the surface epithelium $(*)$, ulceration $(¥)$ and inflammatory granulation tissue (§) of K (A), CHX (B), HA80 (C) and HA150 (D) Groups (Hematoxylin-Eosin X40).

When ulceration values were evaluated, the amount of ulceration on day 7 was lower at a statistically significant level in HA150 Group than in the other groups. In addition, less ulceration was detected in CHX Group than K and HA80 Group. On day 14, a smaller amount of ulceration was detected in HA150 Group than in the other groups, and this difference was statistically significant. The ulceration amounts between $\mathrm{K}$, CHX and HA80 Groups were at similar levels. When the ulceration values were evaluated on day 21, ulceration was lower in HA80 and HA150 at a statistically significant level compared to the other groups. According to the results obtained in this study, when epithelization and ulceration values were evaluated together, it was found that 150 $\mathrm{mg} / \mathrm{kg}$ humic acid increased wound healing at a significant level. It was also concluded that chlorhexidine did not disrupt healing (Figure 1,2 and 3) .

Wound healing is a quite complex response process to tissue injury, and consists of interconnected and intertwined stages like inflammation, proliferation and maturation. Inflammation, which is the first step of recovery, gives the tissue a kind of resistance to microbial contamination. ${ }^{32}$ Infection in the wound area must be prevented in order for wound healing to occur in a problem-free manner. Anti-inflammatory effect is required to shorten recovery time. ${ }^{33}$
In their study, Knuuttila et $a l .{ }^{34}$ reported that various concentrations of chlorhexidine had an anti-inflammatory effect, and reduced different types of leukocytes. Hoffman et al. ${ }^{35}$ reported that $0.1 \%$ chlorhexidine yielded successful results in reducing inflammation. In a study conducted on rats by Van Rensburg et al. ${ }^{36}$, they detected antiinflammatory effects of potassium humate, and reported at the end of their study that the humic acid solution $(61 \mathrm{mg} / \mathrm{kg})$ obtained from lignite was as effective as prednisolone (steroid group), which is known to have an anti-inflammatory effect in suppressing the edema induced in the ears of the rats. Calisir et al. ${ }^{37}$ conducted an experimental periodontitis study, and found that $80 \mathrm{mg} / \mathrm{kg}$ humic acid, which they applied locally, increased the inflammatory cell infiltration rate, the $80 \mathrm{mg} / \mathrm{kg}$ and $150 \mathrm{mg} / \mathrm{kg}$ of humic acid that they applied systemically reduced inflammatory cell infiltration rates. In the present study, the PNL and MNL numbers were evaluated to have an idea on the anti-inflammatory effects of humic acid. Polymorphonuclear leukocytes and mononuclear leukocytes play important roles in the defense of the live tissue against microbial contamination in inflammatory reactions. The number of these cells increases in the presence of bacterial infections, and they quickly migrate to the inflammatory zone. As a result of the findings of the present study, the difference between groups in terms of the number of PNL cells on day 7,14 and 21 was not statistically significant; and the difference between groups in terms of the number of MNL cells on day 7, 14 and 21 was not statistically significant. However, it can be argued that humic acid has anti-inflammatory properties since it reduces inflammatory cells.

Cellular activity is dominant in the proliferation stage of wound healing. ${ }^{38}$ In this stage, it is noted that there is pink granular tissue formation that contains inflammatory cells, fibroblasts and newly-developing blood vessels. Fibroblasts begin to synthesize new non-cellular matrix and immature Type III collagen in response to the cytokines and growth factors released from the inflammatory cells in the wound area. Also, the stimulated fibroblasts secret a 
number of growth factors, which support the healing process by creating a "feedback cycle". Collagen accumulation increases the resistance of the wound to stretching in a fast way. ${ }^{39}$

In their cell culture study, Goldschmidt et $a l .{ }^{40}$ showed that chlorhexidine at a rate of $0.01 \%$ or above caused cell death in human gum fibroblasts. In another in-vitro study conducted by Alleyn $^{41}$, they reported that $0.12 \%$ chlorhexidine reduced the binding of fibroblasts on dentin. Unlike these studies, Mariano et al. ${ }^{28}$ conducted a study and found a large amount of collagen fiber and a small number of fibroblasts in the group which received $2 \%$ chlorhexidine. Cheng et al. ${ }^{42}$ argued that humic acid caused oxidative DNA damage, growth delay and apoptosis in human primary fibroblasts. Kreminzki et al. ${ }^{43}$ conducted another study and argued that turban, which constituted the source of humic acid, had proangiogenic properties. However, there are not enough studies in the literature supporting these studies or proving the opposite.

In the present study, when the fibroblast values on days 7, 14 and 21 were evaluated, no statistically significant differences were detected among the groups. Given these results, it was concluded that the application of humic acid had no positive effects on fibroblasts. The vascularization level in Group $\mathrm{K}$ on day 7 was higher than the vascularization level in CHX and HA80 Group. Similarly, the vascularization level in HA150 Group was higher at a statistically significant level than the level of vascularization in CHX and HA80 Group. However, there was no difference in the vascularization levels of the groups on day 14 and 21. As a result of the findings of the present study, it is possible to speculate that humic acid has a positive effect on wound healing by increasing vascularization.

Measuring the length, width and depth of the wound is an important part of wound evaluation. Compared to defining statements like "good" or "getting better", measuring the size of the wound is an objective proof of wound healing. In the present study, after the tissues taken from the palates of the rats on days 7,14 , and 21 were fixed, the photos taken under X8 magnification in the stereomicroscope were transferred to the computer medium, and it was aimed that objective measurements were made.

Mariano et $a l^{28}$ conducted a study on rats, and reported that $2 \%$ chlorhexidine and metronidazole were very effective in closing wounds at the end of day 6 . Hammad et al. ${ }^{44}$ reported that $0.2 \%$ chlorhexidine gel showed a very good effect in reducing the wound surface on days 7 and 14 compared to the group to which they applied allantoin. Similar to our study, Calisir et al. $^{24}$ compared the concentrations of $0.09 \%$ saline, $0.05 \%$ chlorhexidine, and $80 \mathrm{mg} / \mathrm{kg}$ of humic acid, and they found on days 7 and 14 of the trial that the groups with chlorhexidine and humic acid were better at closing the wound surfaces than the groups that received saline. In the same study, it was also found that chlorhexidine and humic acid had similar levels of activity when compared among the groups. On day 21 of the trial, they reported that humic acid is superior in closing wound surfaces compared among the groups.

In the present study, when the wound surface areas between the groups were compared, it was determined that there were no differences between the healing of wound surfaces on day 7 and 14; however, on day 21, the improvement in the wound surface in HA150 Group was better at a statistically significant level than the improvement in the wound surfaces of the K, CHX and HA80 Groups.

When the intragroup wound surface areas were compared, no significant differences were detected in the $\mathrm{K}$ group among wound surface measurements on days 7,14 and 21. As a result of wound area measurements made in the CHX Group, the wound healing on day 21 was better compared to that on day 7 , and the wound healing rates on the other days were similar. As a result of wound area measurements made in HA80 Group, the wound healing on day 14 was better than that on day 7. Similarly, the wound healing on day 21 was better than that on day 7 . The wound healing on day 21 was better than the wound healing on day 7 in HA150 Group. No significant differences were detected between the wound healing 
measurements on day 7 and 14, and between day 14 and 21 . As a result, in the present study, it was found that $150 \mathrm{mg} / \mathrm{kg}$ humic acid was very effective in closing wound surface. It was also found that chlorhexidine, which was used in the study, had no negative effects on accelerating the closure of the wound surface.

\section{CONCLUSIONS}

Within the limitations of this experimental study, it may be argued that the humic acid, which has previously been shown to have antibacterial and anti-inflammatory characteristics, positively affects wound healing in oral cavity. Humic acid treatment has been found to be superior to chlorhexidine, which is widely used in the treatment of oral wounds.

Further studies are needed to investigate the mechanisms or pathways of the healing effect of humic acid on wounds in the mouth. In line with the results obtained here, we believe that the present study will contribute to the literature on clinical use of humic acid.

\section{ACKNOWLEDGEMENTS}

The authors express their sincere gratitude to Prof. Dr. Ahmet Tutar and Asst. Prof. Ziynet Çınar support in this study. This study was financially supported by the Scientific Research Project Fund of Cumhuriyet University under the project number Diş-216.

\section{Lokal Hümik Uygulamasının Yara İyileşmesi Üzerine Etkisinin Değerlendirilmesi}

\section{ÖZ}

Amaç: Bu çalışmanın amacı; hümik asitin topikal olarak uygulanmasının ratlarda ăgı mukozasındaki yara iyileşmesine etkilerinin, histopatolojik ve histomorfometrik olarak araştırılmasıdır. Gereç ve Yöntemler: Denek olarak 12 haftalı, ortalama ăgırlıklarl 280-300 gr olan Wistar cinsi 72 adet erkek rat kullanıldı. Ratlar rastgele seçilerek hiç bir ajan uygulanmayan kontrol grubu (K), klorheksidin (\%0.12) grubu (CHX), $80 \mathrm{mg} / \mathrm{kg}$ hümik asit grubu (HA80) ve $150 \mathrm{mg} / \mathrm{kg}$ hümik asit grubu (HA150) olmak üzere 4 ana gruba ayrlldr. Ratlarda palatinal bölgede, punch ile $5 \mathrm{~mm}$ çapında mukozal defekt oluşturuldu. Bu gruplar kendi içerisinde 7., 14. ve 21. günlerde sakrifiye edilmek üzere 3 alt gruba ayrldi. Ratlar sakrifiye edildikten sonra histopatolojik inceleme için doku örnekleri alınd. Histopatolojik değerlendirmede; epitelizasyon, ülserasyon, polimorfo nükleer lökositler (PNL), mononükleer hücreler (MNL), fibroblast ve vaskülarizasyona bakıldı. Ayrıca doku örnekleri histomorfometrik inceleme için fotoğraflanarak bilgisayar ortamına aktarıldı. Bulgular: Yapılan istatistiksel analiz sonucunda tüm gruplar arasında 7.,14. ve 21. günlerde epitelizasyon derecesi, PNL ve $M N L$ hücre infiltratı açısından anlamlı bir fark bulunmadl. HA150 grubundaki ülsere alanlar diğer gruplara oranla daha az miktardayd ve bu fark istatistiksel olarak anlamllydl $(p<0,05)$. Vaskülarizasyon değerlerine bakıldığında 7. günde K grubu ve HA150 grubu daha iyi sonuçlar gösterdi $(p<0,05)$. 14. ve 21. günlerde ise gruplar arasında anlamlı bir fark bulunmadı ( $>>0,05)$. Yara yüzey alan ölçümleri, HA150 grubunda diğer gruplara klyasla daha düşük miktardaydl ve bu sonuç, HA150 grubundaki iyileşmenin daha iyi olduğunu gösterdi (p<0,05). Sonuç: Bu çalışmanın sonucunda hümik asitin, ă̆ız boşluğundaki yara iyileşmesini arttırdığ görüldü. Ayrıca klorheksidinin yara iyileşmesini olumsuz yönde etkilemediği tespit edildi. Anahtar Kelimeler: Yara, palatinal mukoza, klorheksidin, hümik asit.

\section{REFERENCES}

1. Hunt TK. Basic principles of wound healing. Journal of Trauma and Acute Care Surgery. 1990;30:122-128.

2. Pereira RF, Bartolo PJ. Traditional therapies for skin wound healing. Advances in wound care. 2016;5(5):208-229.

3. Han G, Ceilley R. Chronic wound healing: a review of current management and treatments. Advances in therapy. 2017;34(3):599-610.

4. Krausz AE, Adler BL, Cabral V, et al. Curcuminencapsulated nanoparticles as innovative antimicrobial and wound healing agent. Nanomedicine: Nanotechnology, Biology and Medicine. 2015;11(1):195-206.

5. Low SB, Ciancio SG. Reviewing nonsurgical periodontal therapy. The Journal of the American Dental Association. 1990;121(4):467-470. 
6. Marti S, Schwartzkopf-Genswein KS, Janzen ED, Meléndez DM, Gellatly D, Pajor EA. Use of topical healing agents on scrotal wounds after surgical castration in weaned beef calves. The Canadian Veterinary Journal. 2017;58(10):1081.

7. Oryan A, Alemzadeh E, Moshiri A. Biological properties and therapeutic activities of honey in wound healing: A narrative review and meta-analysis. Journal of tissue viability. 2016;25(2):98-118.

8. Lev-Tov H. Topical valsartan increases the healing pressure on wounds. Science Translational Medicine. 2017;9(415):eaaq1231.

9. Schepetkin I, Khlebnikov A, Kwon BS. Medical drugs from humus matter: focus on mumie. Drug development research. 2002;57(3):140-159.

10. Burdon J. Are the traditional concepts of the structures of humic substances realistic? Soil science. 2001;166(11):752-769.

11. Davies G, Ghabbour EA, Steelink C. Humic acids: Marvelous products of soil chemistry. Journal of Chemical Education. 2001;78(12):1609.

12. Kurková M, Klika Z, Kliková C, Havel J. Humic acids from oxidized coals: I. Elemental composition, titration curves, heavy metals in HA samples, nuclear magnetic resonance spectra of $\mathrm{HAs}$ and infrared spectroscopy. Chemosphere. 2004;54(8):1237-1245.

13. Islam KMS, Schuhmacher A, Gropp J. Humic acid substances in animal agriculture. Pakistan Journal of nutrition. 2005;4(3):126-134.

14. Bernacchi F, Ponzanelli I, Minunni M, Falezza A, Loprieno N, Barale R. In vivo cytogenetic effects of natural humic acid. Mutagenesis. 1996;11(5):467-469.

15. Santos Ad, Botero WG, Bellin IC, et al. Interaction between humic substances and metallic ions: a selectivity study of humic substances and their possible therapeutic application. Journal of the Brazilian Chemical Society. 2007;18(4):824-830.

16. Thiel K, Helbig B, Klöcking R, Wutzler P, Sprössig $\mathrm{M}$, Schweizer H. Comparison of the in vitro activities of ammonium humate and of enzymically oxidized chlorogenic and caffeic acids against type 1 and type 2 human herpes virus (author's transl). Die Pharmazie. 1981;36(1):50-53.
17. Lotosh T. Experimental bases and prospects for the use of humic acid preparations from peat in medicine and agricultural production. Paper presented at: Nauchnye doklady vysshei shkoly. Biologicheskie nauki1991.

18. Laub R. Acute systemic toxicity studies of natural product and synthetic humates. Laub BioChem Corp, August. 1998.

19. Tkachenko S, Rutskiı̌ V, Grachev I. under the effect of mumie-asyl. Ortopediia Travmatologiia I Protezirovanie [Ortop Travmatol Profitez]. 1979:4952.

20. Kel'ginbaev N, Sorokina V, Stefanidu A, Ismailova V. Treatment of long tubular bone fractures with Mumie Assil preparations in experiments and clinical conditions. Eksperimental'naia khirurgiia $i$ anesteziologiia. 1973;18(4):31-35.

21. Dürre K. Austestung antiviraler Substanzen an der rezidivierenden kutanen Herpes-simplex-VirusInfektion der Maus unter Berücksichtigung des Einflusses von Penetrationsvermittlern 1992.

22. Vucskits A, Hullár I, Bersényi A, Andrásofszky E, Kulcsár M, Szabó J. Effect of fulvic and humic acids on performance, immune response and thyroid function in rats. Journal of Animal Physiology and Animal Nutrition. 2010;94(6):721-728.

23. Ji Y, Zhang A, Chen X, Che X, Zhou K, Wang Z. Sodium humate accelerates cutaneous wound healing by activating TGF- $\beta /$ Smads signaling pathway in rats. Acta Pharmaceutica Sinica B. 2016;6(2):132-140.

24. Çalışır M, Akpınar A, Talmaç AC, Lektemur Alpan A, Göze ÖF. Humic Acid Enhances Wound Healing in the Rat Palate. Evidence-Based Complementary and Alternative Medicine. 2018;2018.

25. de Melo BAG, Motta FL, Santana MHA. Humic acids: Structural properties and multiple functionalities for novel technological developments. Materials Science and Engineering: C. 2016;62:967-974.

26. Singer AJ, Clark RA. Cutaneous wound healing. New England journal of medicine. 1999;341(10):738746.

27. Gau R-J, Yang H-L, Chow S-N, Suen J-L, Lu F-J. Humic acid suppresses the LPS-induced expression of cell-surface adhesion proteins through the inhibition of 
NF-кB activation. Toxicology and applied pharmacology. 2000;166(1):59-67.

28. Mariano RC, Oliveira MR, Silva LC, Ferreira S, Júnior IRG, de Carvalho Silva A. Effect of topical application of chlorhexidine and metronidazole on the tissue repair of palatal wounds of rats: a clinical and histomorphometric study. Oral surgery, oral medicine, oral pathology and oral radiology. 2015;119(5):505513.

29. da Silveira Teixeira D, de Figueiredo MAZ, Cherubini K, Garcia MCR, de Oliveira SD, Salum FG. Topical chlorhexidine, povidone-iodine and erythromycin in the repair of traumatic ulcers on the rat tongue: Clinical, histological and microbiological evaluation. Archives of oral biology. 2018;87:218-225.

30. Abshenas J, Kheirandish R, Salary AR. Gastroprotective effect of mummy on induced gastric ulcer in rats. Comparative Clinical Pathology. 2014;23(2):305-309.

31. Brzozowski T, Dembiński A, Konturek S. Influence of Tołpa Peat Preparation on gastroprotection and on gastric and duodenal ulcers. Acta poloniae pharmaceutica. 1994;51(1):103-107.

32. Khedr RI, El Dine FMB, Menesy HMED, Abdelatif AA, Fouad AA. Detection of the Timing of Human Skin Wounds by Immunohistochemical Analysis of CD14. Arab Journal of Forensic Sciences \& Forensic Medicine (AJFSFM). 2020;1(10):1357.

33. Süntar IP, Akkol EK, Y1lmazer D, et al. Investigations on the in vivo wound healing potential of Hypericum perforatum L. Journal of ethnopharmacology. 2010;127(2):468-477.

34. Knuuttila M, Paunio KU, Mielityinen H. Effect of chlorhexidine gluconate on acute nonmicrobial inflammation reaction. Journal of periodontology. 1978;49(2):96-101.

35. Hoffmann T, Bruhn G, Richter S, Netuschil L, Brecx M. Clinical controlled study on plaque and gingivitis reduction under long-term use of low-dose chlorhexidine solutions in a population exhibiting good oral hygiene. Clinical oral investigations. 2001;5(2):89-95.
36. Van Rensburg C, Snyman J, Mokoele T, Cromarty A. Brown coal derived humate inhibits contact hypersensitivity; an efficacy, toxicity and teratogenicity study in rats. Inflammation. 2007;30(5):148-152.

37. Çalışır M, Akpınar A, Poyraz Ö, Göze F, Çınar Z. The histopathological and morphometric investigation of the effects of systemically administered humic acid on alveolar bone loss in ligature-induced periodontitis in rats. Journal of Periodontal Research. 2016;51(4):499-507.

38. Nagy JA, Dvorak AM, Dvorak HF. VEGF-A and the induction of pathological angiogenesis. Annu. Rev. Pathol. Mech. Dis. 2007;2:251-275.

39. Vivek Shetty CNB. Wound Healing. Peteron's Principles of Oral and Maxillofacial Surgery 2nd ed. 2004:3-16.

40. Goldschmidt $\mathrm{P}, \quad$ Cogen $\mathrm{R}$, Taubman $\mathrm{S}$. Cytopathologic effects of chlorhexidine on human cells. Journal of periodontology. 1977;48(4):212-215.

41. Alleyn CD, O'Neal RB, Strong SL, Scheidt MJ, Van Dyke TE, McPherson JC. The effect of chlorhexidine treatment of root surfaces on the attachment of human gingival fibroblasts in vitro. Journal of periodontology. 1991;62(7):434-438.

42. Cheng M-L, Ho H-Y, Huang Y-W, Lu F-J, Chiu DT-Y. Humic Acid Induces Oxidative DNA Damage, Growth Retardation, and Apoptosis in Human Primary Fibroblasts. Experimental Biology and Medicine. 2003;228(4):413-423.

43. Krzemiński TF, Nożyński JK, Grzyb J, et al. Angiogenesis and cardioprotection after TNF $\alpha$ inducer-Tolpa Peat Preparation treatment in rat's hearts after experimental myocardial infarction in vivo. Vascular pharmacology. 2005;43(3):164-170.

44. Hammad H, Hammad M, Abdelhadi I, Khalifeh M. Effects of topically applied agents on intra-oral wound healing in a rat model: a clinical and histomorphometric study. International journal of dental hygiene. 2011;9(1):9-16. 